\title{
Cerium Oxide/Polypyrrole Nanocomposite as the Matrix for Cholesterol Biosensor
}

\author{
Ta Thi Nhat Anh $\mathbb{D}^{1,2}$ Vu Van Thu ${ }^{1},{ }^{3}$ Hai-Son Dang, ${ }^{4}$ Vuong-Hung Pham $\mathbb{D}^{1}$, \\ and Phuong Dinh Tam $\left.{ }^{4}\right)^{4}$ \\ ${ }^{1}$ Advanced Institute for Science and Technology, Hanoi University of Science and Technology, Vietnam \\ ${ }^{2}$ Vinh Phuc Technology Economic College, No. 10 Hung Vuong Road, Vinhyen, Vinh Phuc, Vietnam \\ ${ }^{3}$ Faculty of Occupational Safety and Health, Trade Union University, Hanoi, Vietnam \\ ${ }^{4}$ Faculty of Material Science and Engineering, Phenikaa University, Hanoi 12116, Vietnam
}

Correspondence should be addressed to Vuong-Hung Pham; vuong.phamhung@hust.edu.vn and Phuong Dinh Tam; tam.phuongdinh@phenikaa-uni.edu.vn

Received 1 November 2020; Revised 5 December 2020; Accepted 13 January 2021; Published 4 February 2021

Academic Editor: Thomas J. Farmer

Copyright (C) 2021 Ta Thi Nhat Anh et al. This is an open access article distributed under the Creative Commons Attribution License, which permits unrestricted use, distribution, and reproduction in any medium, provided the original work is properly cited.

\begin{abstract}
A nanocomposite comprising cerium oxide nanoparticles $\left(\mathrm{CeO}_{2} \mathrm{NPs}\right)$ and polypyrrole (PPy) was fabricated onto a microelectrode for cholesterol sensing application. The cholesterol oxidase ( $\mathrm{ChOx}$ ) was immobilized on the $\mathrm{CeO}_{2} \mathrm{NP}_{\mathrm{N}} / \mathrm{PPy} /$ electrode by the physical adsorption route. The structure and morphology of the $\mathrm{CeO}_{2} \mathrm{NPs} / \mathrm{PPy}$ nanocomposite were characterized by X-ray diffraction, field emission scanning electron microscopy, and energy dispersive X-ray spectroscopy. Results showed that the $\mathrm{ChOx} / \mathrm{CeO}_{2} \mathrm{NPs} / \mathrm{PPy} /$ electrode was linearly related with cholesterol in the range of 50 to $500 \mathrm{mg} / \mathrm{dL}$. The sensitivity of $\mathrm{ChOx} / \mathrm{CeO}_{2} \mathrm{NPs} / \mathrm{PPy} /$ electrode was $5.7 \times 10^{-6} \mathrm{~mA} / \mathrm{mg} \cdot \mathrm{dL}^{-1}$. The optimal parameters, including $\mathrm{pH}$ value and temperature, and selectivity, storage stability, and reproducibility of $\mathrm{ChOx} / \mathrm{CeO}_{2} \mathrm{NPs} / \mathrm{PPy} /$ electrode were investigated.
\end{abstract}

\section{Introduction}

Cholesterol is an important component of cell membranes. Normally, the total cholesterol amount in the human blood at less than $200 \mathrm{mg} / \mathrm{dL}$ represents the desirable level, from 200 to $239 \mathrm{mg} / \mathrm{dL}$ is the borderline high for heart disease, and above $240 \mathrm{mg} / \mathrm{dL}$ corresponds to high blood cholesterol [1]. High cholesterol levels in the human blood are usually associated to heart diseases, diabetes, nephrosis, and obstructive jaundice [2]. Thus, cholesterol level estimation is extremely important in clinical diagnosis. The different approaches, including high-performance liquid chromatography [3-6], near-infrared (IR) spectra [7-9], and colorimetric assay [10-12], have been used for cholesterol level detection. However, the abovementioned approaches are expensive and time consuming and require large amounts of serum samples $[13,14]$. Therefore, a rapid, robust, and sensitive cholesterol detection method should be developed [15].
Electrochemical biosensors, owing to their advantages of simplicity, selectivity, rapid response, stability, low cost, and ease of fabrication [15-20], have been recently studied to detect cholesterol levels. Tiwari and Gong [20] reported a novel chitosan (CHIT)/ $/ \mathrm{SiO}_{2} /$ multiwalled carbon nanotube (MWCNT)/electrode-based cholesterol biosensor. They established the linear relationship between oxidation current response and cholesterol concentrations to be in the range of $5.0-5000 \mu \mathrm{g} / \mathrm{mL}$, a response time of $5 \mathrm{~s}$, and a sensitivity of $3.4 \mathrm{nA} / \mathrm{mg} \mathrm{dL}^{-1}$. Wisitsoraat et al. [21] developed a new cholesterol biosensor by using carbon nanotubes (CNT) directly growth on a glass-based chip via the low-temperature chemical vapor deposition process. They determined the linear detection range to be between 50 and $400 \mathrm{mg} / \mathrm{dL}$ with a sensitivity of $0.0512 \mathrm{nA} / \mathrm{mg} \cdot \mathrm{dL}^{-1}$. Khan et al. [22] studied a cholesterol biosensor by using nano-ZnO-CHIT as the sensing element. They found that the granular porous morphology of nano-ZnO-CHIT could provide an even better 


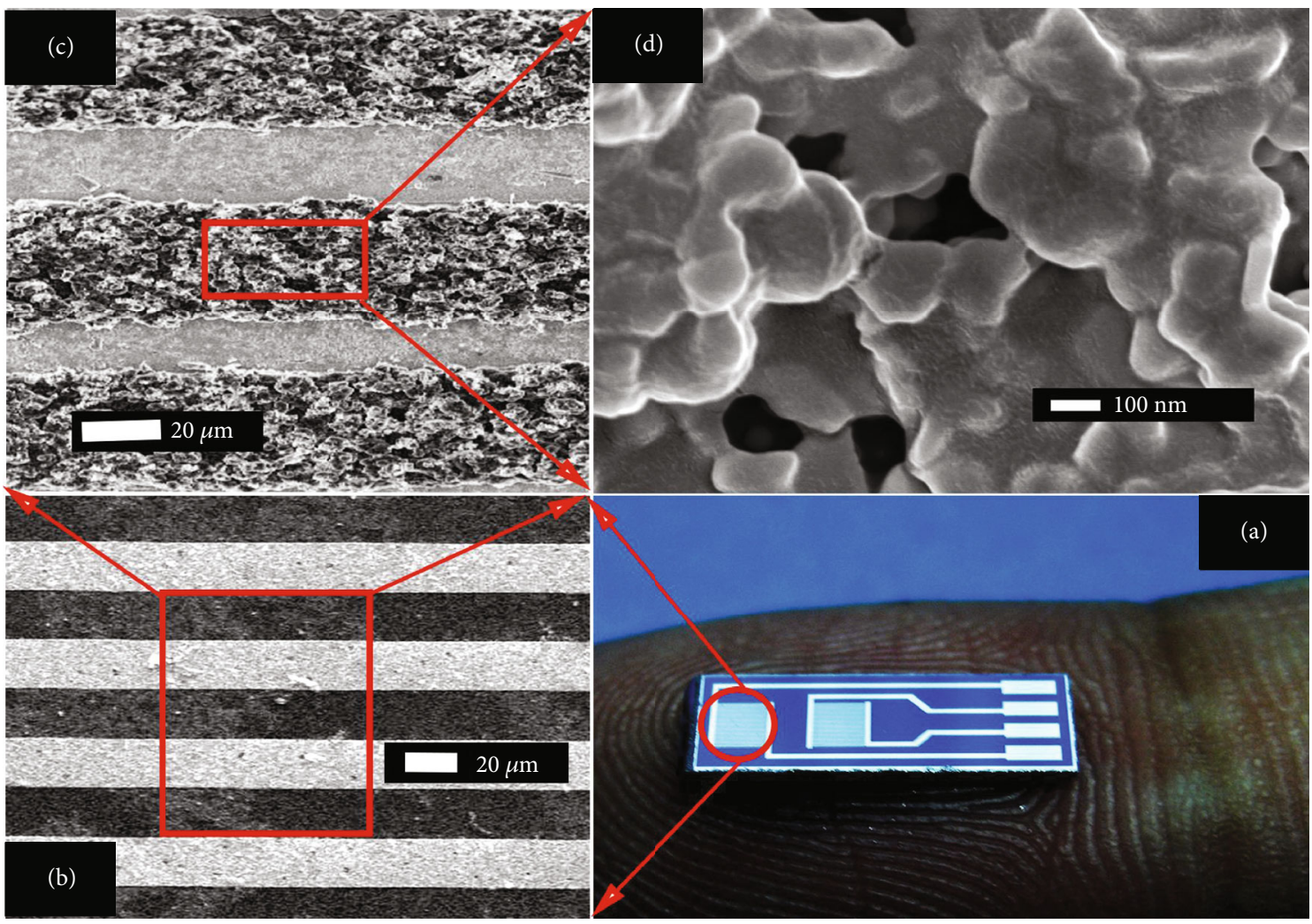

Scheme 1: Schematic of cholesterol biosensor fabrication, (a) microelectrode, and (b)-(d) magnification of CeO $\mathrm{NPs}_{2} / \mathrm{PPy}_{\text {nanocomposite- }}$ modified electrode.

biocompatible environment for the enzymes. The developed sensor presented a linearity from 5 to $300 \mathrm{mg} \cdot \mathrm{dL}^{-1}$ and a shelf life of 85 days. Ansari et al. [23] studied the CHIT-tin oxide $\left(\mathrm{SnO}_{2}\right)$ nano-biocomposite film for cholesterol biosensor development. They showed that $\mathrm{ChOx} / \mathrm{CHIT}-\mathrm{SnO}_{2} / \mathrm{ITO}$ (indium-tin-oxide) was more stable than the $\mathrm{ChOx} / \mathrm{CHI}-$ T/ITO bioelectrode, and it presented a high sensitivity of $34.7 \mathrm{~mA} / \mathrm{mgdL}^{-1} \mathrm{~cm}^{2}$, a linear response in the range of $10-$ $400 \mathrm{mg} / \mathrm{dL}$, and a low detection limit of $5 \mathrm{mg} / \mathrm{dL}$.

Polypyrrole (PPy), a functional conducting polymer material, is usually considered to be a p-type material with good thermal and high environmental stability, low oxidation potential, and high conductivity [24]. In recent years, PPy-based nanocomposites with different nanomaterials, such as CNT [25], metal oxide [26], dodecylbenzene sulfonate (DBS) [27], have attracted wide attention for biosensor development owing to their large specific surface areas, high conductivity, and biocompatibility. Singh et al. [25] studied a biosensor by using PPy/MWCNT as the mediator for cholesterol sensing. The PPy and carboxy-functionalized MWCNT were electrochemicaly synthesized onto the ITO electrode by using p-toluene sulfonic acid (PTS). Moreover, ChOx and cholesterol esterase $(\mathrm{ChEt})$ were immobilized onto the PPyMWCNT/ITO electrode by using $N$-ethyl- $N$-(3-dimethylaminopropyl) carbodiimide and $N$-hydroxy succinimide chemistry. The ChEt-ChOx/PPy-MWCNT/PTS/ITO electrode presented a rapid response time of approximately $9 \mathrm{~s}$ with a detection limit of $0.04 \mathrm{mM} / \mathrm{L}$. They also demonstrated that the developed cholesterol biosensor could be easily fabricated, had a rapid response time, and was useful in blood serum sampling. A novel amperometric biosensor based on a conducting polymer and DBS-modified electrode was successfully developed by Ozer et al. [27]. ChOx was physically entrapped onto the PPy-DBS film surface; then, the cholesterol concentration was determined by performing an electrochemical detection of the $\mathrm{H}_{2} \mathrm{O}_{2}$ generated in the enzymatic reaction of cholesterol. Their results showed that $90.0 \%$ of the response current of the cholesterol biosensor could be retained after 30 activity assays, and the minimum detectable concentration of $10 \mathrm{nM}$ was also determined. Wang et al. [28] synthesized the $\mathrm{CeO}_{2} / \mathrm{PPy}$ composite for electrochemical sensor application to detect sodium nitrite. The $\mathrm{CeO}_{2} / \mathrm{PPy}$ composite was prepared by in situ compounding and coated on a glassy carbon electrode to obtain the electrochemical sensor. They showed the anode peak current response was proportional to the sodium nitrite concentration in the range $0.125-22.5 \mathrm{mmol} / \mathrm{L}$, and the detection limit was $0.08 \mu \mathrm{mol} / \mathrm{L}$. Nguyet et al. [29] reported a DNA sensor based on the $\mathrm{CeO}_{2} / \mathrm{PPy}$ nanocomposite for Salmonella detection. In situ chemical oxidative polymerization was used to prepare the core-shell $\mathrm{CeO}_{2}-\mathrm{NR} @ \mathrm{PPy}$ nanocomposite, which provided a suitable platform for electrochemical DNA biosensor fabrication. The sDNA/ $\mathrm{CeO}_{2} \mathrm{NRs@PPy/elec-}$ trode response under optimal conditions presented a linearity between 0.01 and $0.4 \mathrm{nM}$ with a sensitivity of $593.7 \Omega \bullet \mathrm{nM}^{-1} \bullet \mathrm{cm}^{-2}$. 


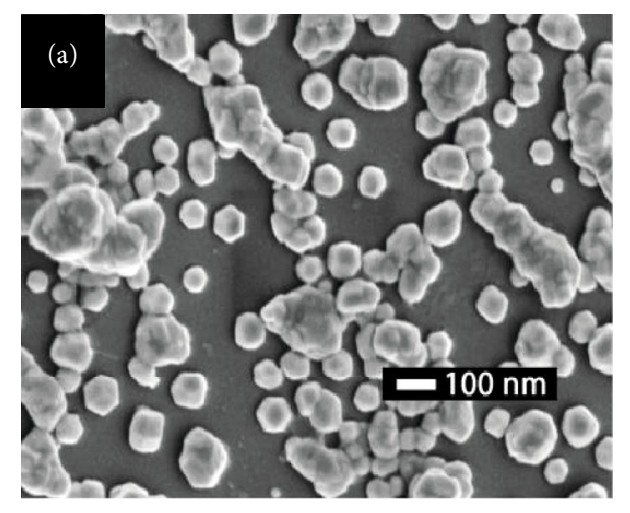

(a)

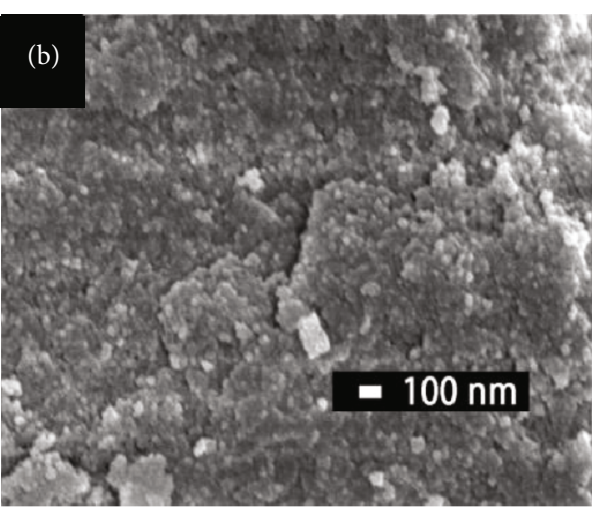

(b)

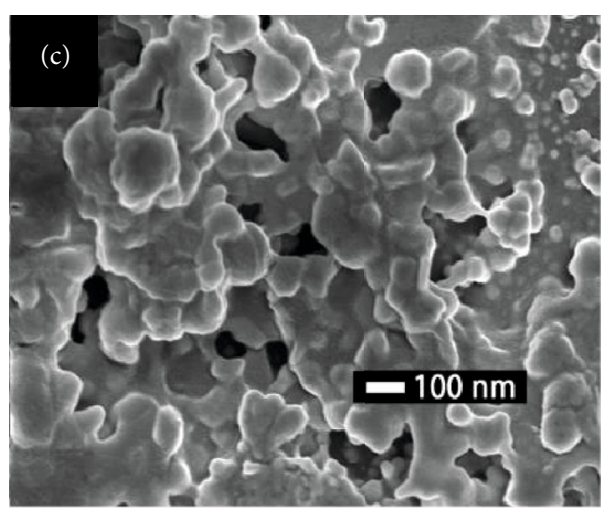

(c)

Figure 1: FE-SEM images of (a) pristine $\mathrm{CeO}_{2} \mathrm{NPs}$, (b) pure PPy, and (c) $\mathrm{CeO}_{2} \mathrm{NPs} / \mathrm{PPy}$ nanocomposite.

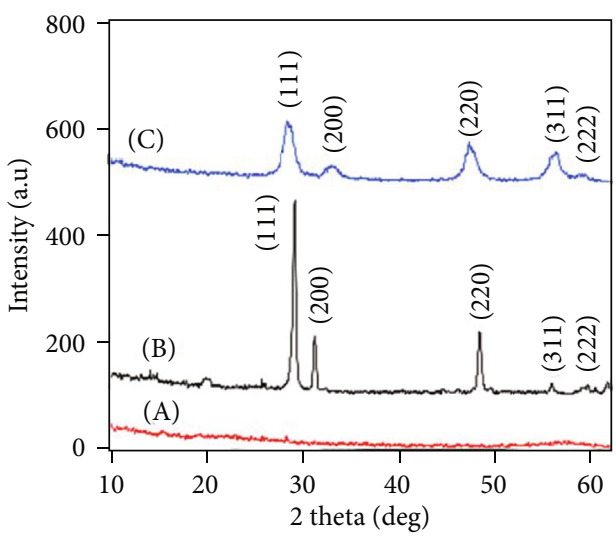

(a)

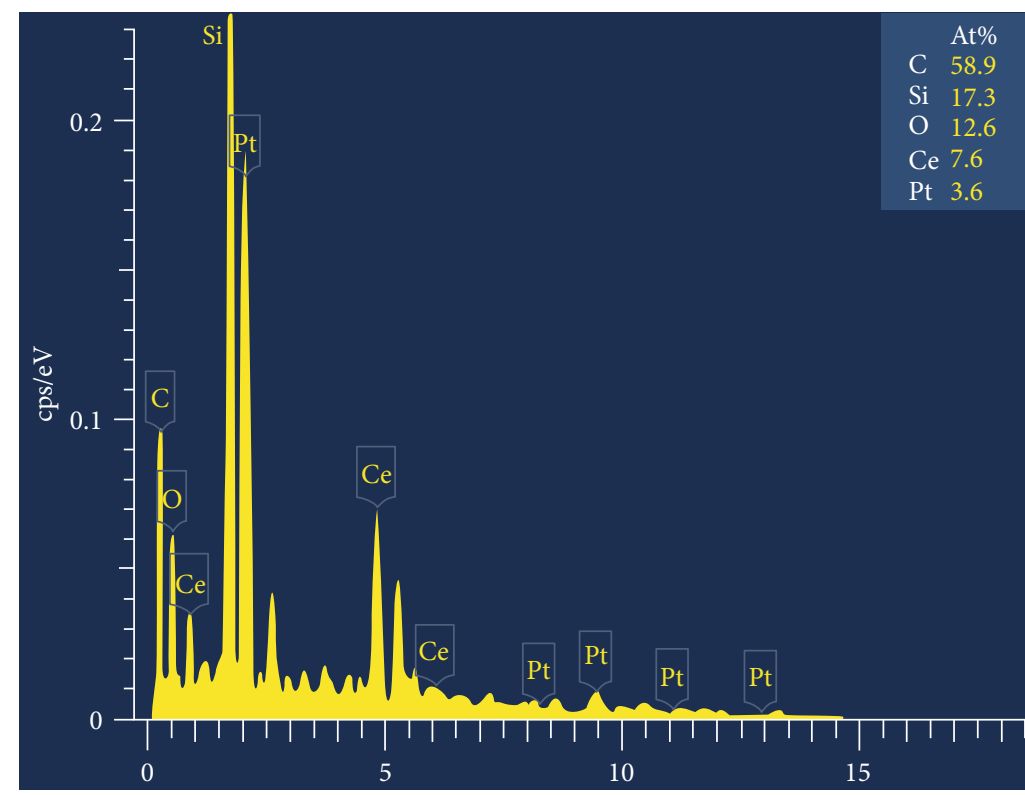

Energy/keV

(b)

Figure 2: (a) XRD patterns of (A) pure PPy, (B) pristine $\mathrm{CeO}_{2} \mathrm{NPs}$, and (C) $\mathrm{CeO}_{2} \mathrm{NPs} / \mathrm{PPy}$ nanocomposite and (b) EDS of CeO 2 NPs/PPy nanocomposite. 
$\mathrm{CeO}_{2} / \mathrm{PPy}$ material-based biosensors have been widely studied for various biosensor applications. However, the reports on cholesterol biosensors, which use $\mathrm{CeO}_{2} / \mathrm{PPy}$ nanomaterials as mediators, are limited. To the best of the author's knowledge, $\mathrm{CeO}_{2} \mathrm{NPs} / \mathrm{PPy}$ nanocomposite based-biosensors have been rarely used in cholesterol detection.

In this study, we developed a cholesterol biosensor by using a $\mathrm{CeO}_{2} \mathrm{NPs} / \mathrm{PPy}$ nanocomposite as the mediator to immobilize ChOx on the electrode surface without using an intermediate linker. The results showed improvements in the performance of cholesterol sensing, which may be due to the synergic effect of PPy and $\mathrm{CeO}_{2}$ NPs. The influencing factors, including $\mathrm{pH}$ value and temperature, and the selectivity, storage stability, and reproducibility of $\mathrm{ChOx} / \mathrm{CeO}_{2}$ NPs/PPy/electrode were highlighted in this work.

\section{Experimental}

2.1. Chemical Reagents. ChOx was procured from SigmaAldrich. The potassium hexacyanoferrate (III) $\left(\mathrm{K}_{3}\left[\mathrm{Fe}(\mathrm{CN})_{6}\right]\right)$, potassium hexacyanoferrate (II) $\left.\left(\mathrm{K}_{4} \mathrm{Fe}(\mathrm{CN})_{6}\right]\right)$, and phosphate buffer saline (PBS) were purchased from Beijing Chemical Reagent (China). Cerium III nitrate hexahydrate $\mathrm{Ce}\left(\mathrm{NO}_{3}\right)_{3} \cdot 6 \mathrm{H}_{2} \mathrm{O} \quad(99.999 \%)$, $\mathrm{CH}_{3} \mathrm{COONH}_{4}$ (99.999\%), cholesterol (95\%), and $\mathrm{KCl}$ purity $\geq 99 \%$ were purchased from Sigma-Aldrich. All solutions were prepared with ultrapure water $(18.2 \mathrm{M} \Omega \cdot \mathrm{cm})$ from a Millipore Milli-Q system.

2.2. $\mathrm{CeO}_{2} \mathrm{NPs} / \mathrm{PPy}$ Nanocomposite Synthesis. In this work, the microelectrode was used as a working electrode for cholesterol biosensor preparation. The sample was fabricated by sputtering $20 \mathrm{~nm}$ of $\mathrm{Cr}$ and $200 \mathrm{~nm}$ of $\mathrm{Au}$ on an approximately $100 \mathrm{~nm}$ thick silicon dioxide layer that was thermally grown on top of a silicon wafer. A saturated $\mathrm{Ag} / \mathrm{AgCl}$ electrode was used as the reference electrode. A platinum plate was used as the counter-electrode. Before the electrode was modified, its surface was cleaned with $\mathrm{KCr}_{2} \mathrm{O}_{7}$ in $98 \% \mathrm{H}_{2} \mathrm{SO}_{4}$. Then, the cleaned electrodes were treated via the cyclic voltammetry $(\mathrm{CV})$ technique with a potential range from -0.5 to $2.1 \mathrm{~V}$ using $0.5 \mathrm{M} \mathrm{H}_{2} \mathrm{SO}_{4}$ as the electrolytes, rinsed with distilled $\mathrm{H}_{2} \mathrm{O}$ until the $\mathrm{pH}$ of the solution was neutral, and dried under nitrogen stream. Subsequently, the $\mathrm{CeO}_{2}$ NPs were electrochemically synthesized in a conventional three-electrode cell via $\mathrm{CV}$ in the range from -0.6 to $1.8 \mathrm{~V}$ with a scanning rate of $100-500 \mathrm{mV} / \mathrm{s}$ at room temperature in the electrolytic solution. The solution contained mixtures of $0.001-0.02 \mathrm{M}$ of $\mathrm{Ce}\left(\mathrm{NO}_{3}\right)_{3} \cdot 6 \mathrm{H}_{2} \mathrm{O}, \quad 0.01 \mathrm{M}$ of $\mathrm{KCl}$, and $0.02 \mathrm{M}$ $\mathrm{CH}_{3} \mathrm{COONH}_{4}$. Finally, the PPy was electrochemically synthesized by galvanostatic polarization using an aqueous oxalic acid solution with $0.1 \mathrm{M}$ pyrrole monomer for 240 seconds at $1 \mathrm{~mA} / \mathrm{cm}^{2}$. After the electrochemical deposition, the $\mathrm{CeO}_{2}$ NPs/PPy-modified electrode was washed with ethanol and distilled water to remove impurities and then dried at room temperature. The schematic of the cholesterol biosensor fabrication is shown in Scheme 1 .

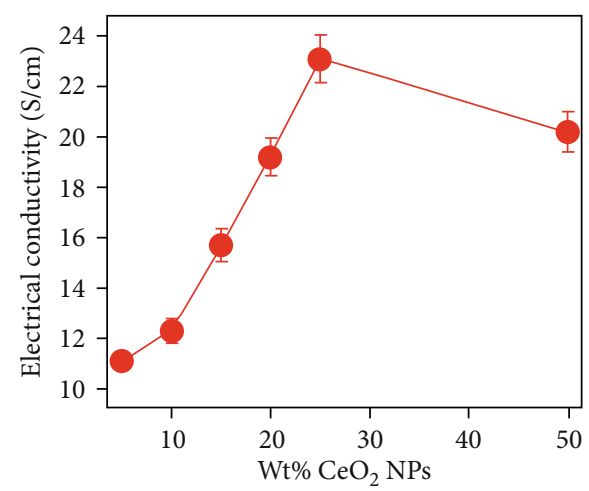

Figure 3: Electrical conductivity of $\mathrm{CeO}_{2} \mathrm{NPs} / \mathrm{PPy}$ nanocomposite with different wt $\%$ of $\mathrm{CeO}_{2} \mathrm{NPs}$.

2.3. Preparation of $\mathrm{ChO} x / \mathrm{CeO}_{2} \mathrm{NPs} / \mathrm{PP} /$ /Electrode. For the ChOx immobilization, the $\mathrm{CeO}_{2}$ NPs/PPy-modified electrode was immersed in an immobilization solution ( $\mathrm{ChOx}$ $1.0 \mathrm{mg} / \mathrm{mL}$ in $0.1 \mathrm{M}$ PBS) for $12 \mathrm{~h}$ to enable the binding of ChOx on the electrode surface through physical adsorption. Then, the $\mathrm{ChOx} / \mathrm{CeO}_{2} \mathrm{NPs} / \mathrm{PPy} /$ electrode was further rinsed with DI water for several times to remove the unbound ChOx. A total of $5 \mu \mathrm{L}$ of Nafion solution was dropped onto the electrode surface to prevent possible enzyme leakage. The $\mathrm{ChOx} / \mathrm{CeO}_{2} \mathrm{NPs} / \mathrm{PPy} /$ electrodes were stored in PBS at $4^{\circ} \mathrm{C}$.

2.4. Electrochemical Measurements for $\mathrm{ChOx} / \mathrm{CeO}$ NPs/PPy/Electrode. The electrochemical measurements were performed using an IM6 impedance analyzer with the IM6THALES software in PBS solutions containing $\mathrm{Fe}(\mathrm{CN})_{6}^{3 / 4-}$ as a redox probe. The $\mathrm{ChOx} / \mathrm{CeO}_{2} \mathrm{NPs} / \mathrm{PPy} /$ electrode was connected to the test and sense probes, and the Pt electrode was connected to the counter-electrode of the IM6 impedance analyzer. The reference electrode was an $\mathrm{Ag} / \mathrm{AgCl}$ electrode. The CV plots were recorded, and the difference in oxidation peak current density was considered the signal produced by $\mathrm{ChOx}$-catalyzed cholesterol oxidation.

\section{Results and Discussion}

3.1. Structural Characterization. The morphological of (a) pristine $\mathrm{CeO}_{2} \mathrm{NPs}$, (b) pure PPy, and (c) $\mathrm{CeO}_{2} \mathrm{NPs} / \mathrm{PPy}$ nanocomposite was characterized through field emission scanning electron microscopy (FE-SEM) (Figure 1). Figure 1(a) indicates the morphology of the pristine $\mathrm{CeO}_{2}$ NPs, which are synthesized in solution contained mixtures of $0.015 \mathrm{M}$ of $\mathrm{Ce}\left(\mathrm{NO}_{3}\right)_{3} \cdot 6 \mathrm{H}_{2} \mathrm{O}, 0.01 \mathrm{M}$ of $\mathrm{KCl}$, and $0.02 \mathrm{M}$ $\mathrm{CH}_{3} \mathrm{COONH}_{4}$ via $\mathrm{CV}$ in the range from -0.6 to $1.8 \mathrm{~V}$. It can be seen that the morphology is uniformly distributed, with a diameter of approximately $80-100 \mathrm{~nm}$. The morphology of the pure PPy with cauliflower-like structure is presented in Figure 1(b). Figure 1(c) shows FE-SEM of the $\mathrm{CeO}_{2}$-NPs/PPy nanocomposite with a slight agglomeration and a diameter of approximately $100-120 \mathrm{~nm}$, which is electrochemically synthesized by galvanostatic polarization using 


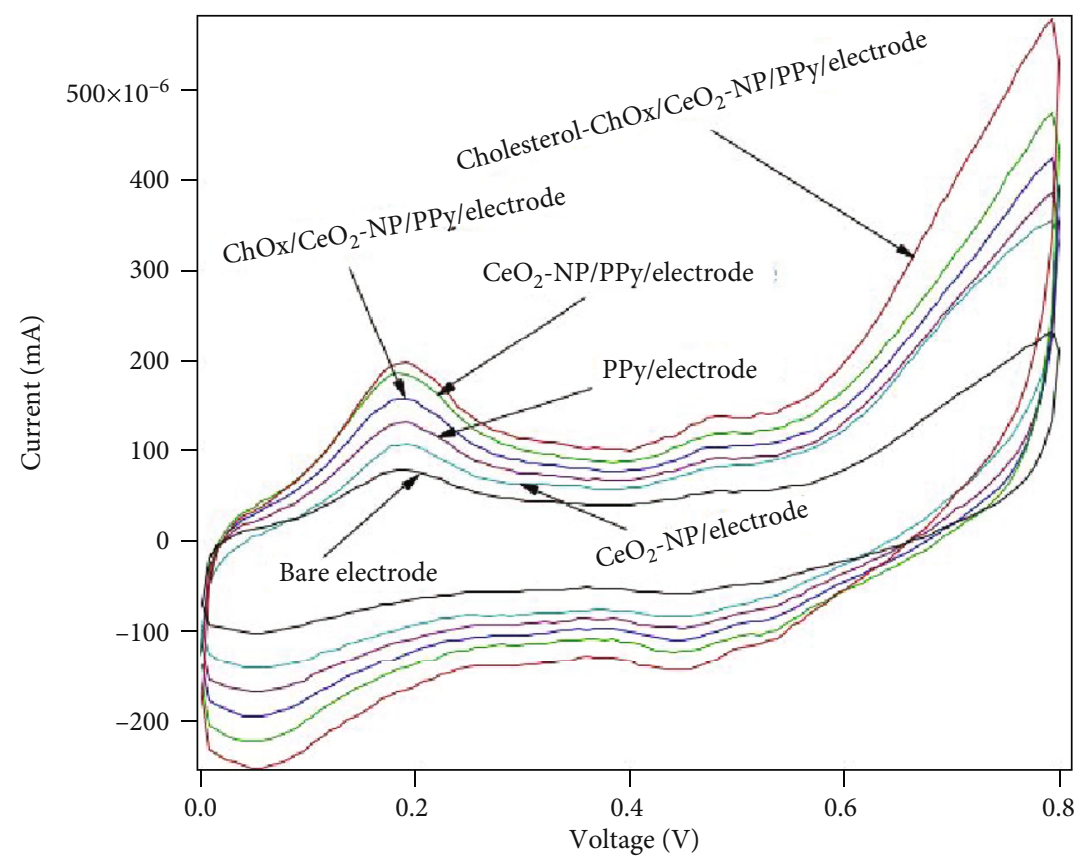

Figure 4: $\mathrm{CV}$ of bare electrode, $\mathrm{CeO}_{2}$-NPs/electrode, PPy/electrode, $\mathrm{CeO}_{2} \mathrm{NPs} / \mathrm{PPy} /$ electrode, $\mathrm{ChOx} / \mathrm{CeO}{ }_{2} \mathrm{NPs} / \mathrm{PPy} / \mathrm{electrode}$, and cholesterol-ChOx/ $\mathrm{CeO}_{2} \mathrm{NPs} / \mathrm{PPy} /$ electrode in PBS solution containing $\mathrm{Fe}(\mathrm{CN})_{6}{ }^{3-/ 4-}$.

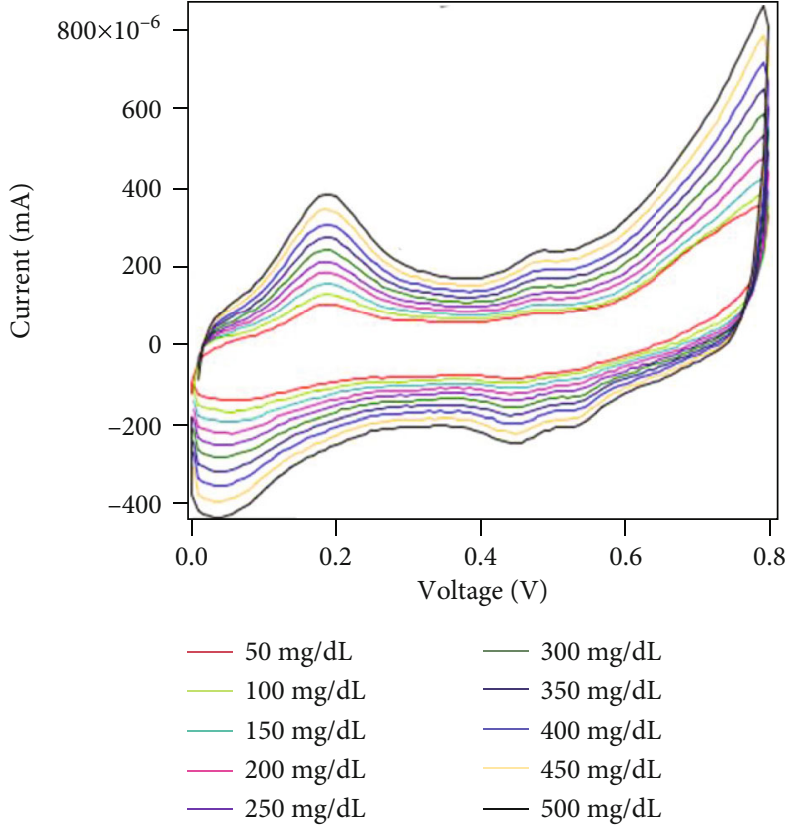

(a)

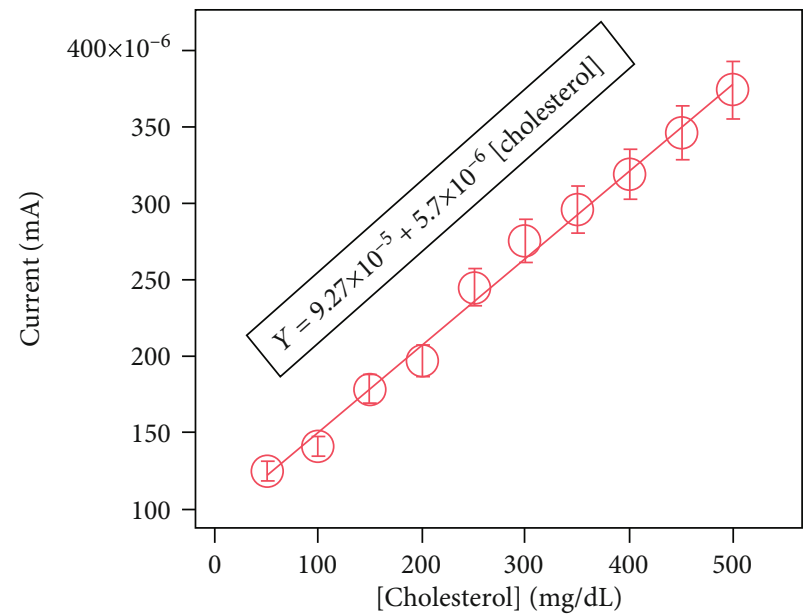

(b)

Figure 5: (a) $\mathrm{CV}$ with varying cholesterol concentrations from 50 to $500 \mathrm{mg} / \mathrm{dL}$ on $\mathrm{ChOx} / \mathrm{CeO}_{2} \mathrm{NPs} / \mathrm{PPy} / \mathrm{electrode}$ in $\mathrm{PBS}$ solution containing $\mathrm{Fe}(\mathrm{CN})_{6}{ }^{3-/ 4-}$ and (b) electrode response as a function of cholesterol concentration.

an aqueous oxalic acid solution with $0.1 \mathrm{M}$ pyrrole monomer for 240 seconds at $1 \mathrm{~mA} / \mathrm{cm}^{2}$.

The X-ray diffraction (XRD) patterns of the (a) pure PPy, (b) pristine $\mathrm{CeO}_{2} \mathrm{NPs}$, and (c) $\mathrm{CeO}_{2}$ NPs/PPy nanocomposite are shown in Figure 2(a). As illustrated in Figure 2(a), (A), the XRD pattern of the pure PPy is amorphous, as no peaks can be defined in its XRD pat- tern. The diffraction peaks found at $28.6^{\circ}, 33.1^{\circ}, 47.6^{\circ}$, $56.5^{\circ}$, and $59.1^{\circ}$ correspond to the (111), (200), (220), (311), and (222) planes with a cubic fluorite structure of the pristine $\mathrm{CeO}_{2} \mathrm{NPs}$, as shown in Figure 2(a), (B). These peaks were indexed using JCPD card no. 34-0394. The XRD pattern of the $\mathrm{CeO}_{2} \mathrm{NPs} / \mathrm{PPy}$ nanocomposite is illustrated in Figure 2(a), (C). The profile of the sample shown 


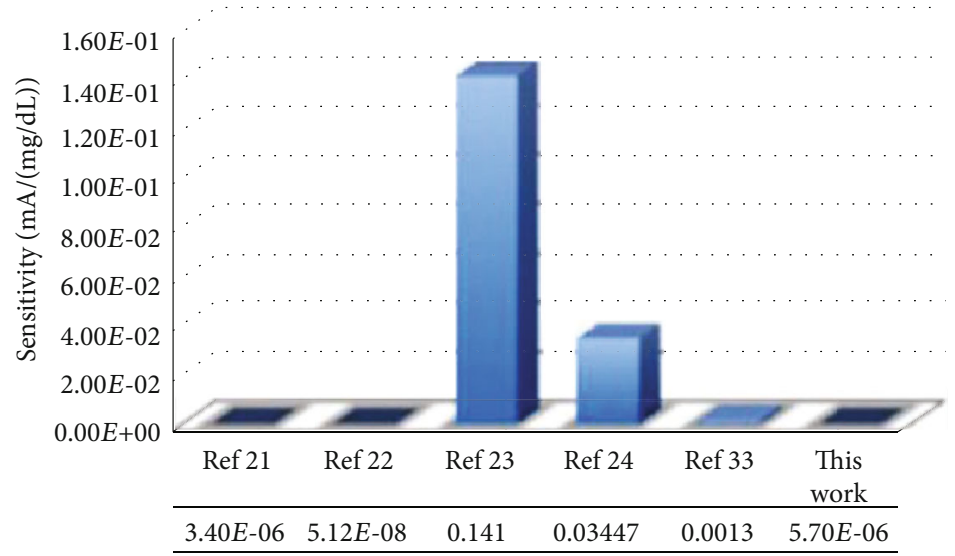

(a)

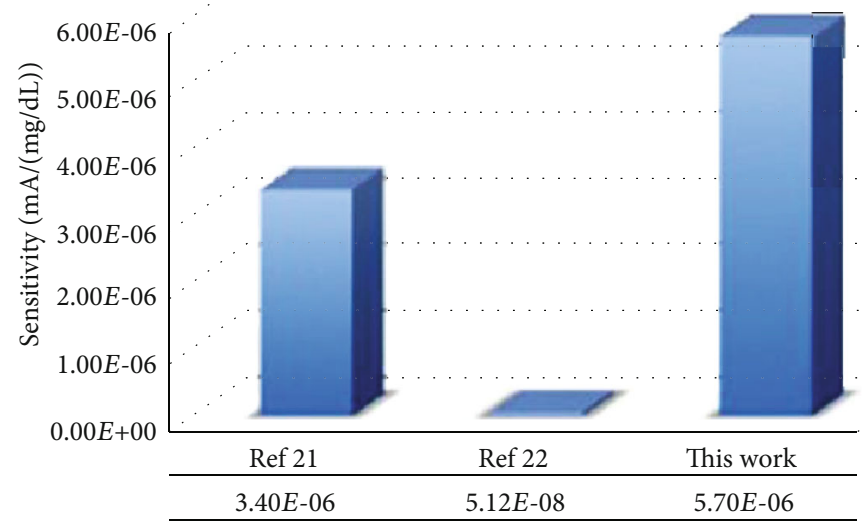

(b)

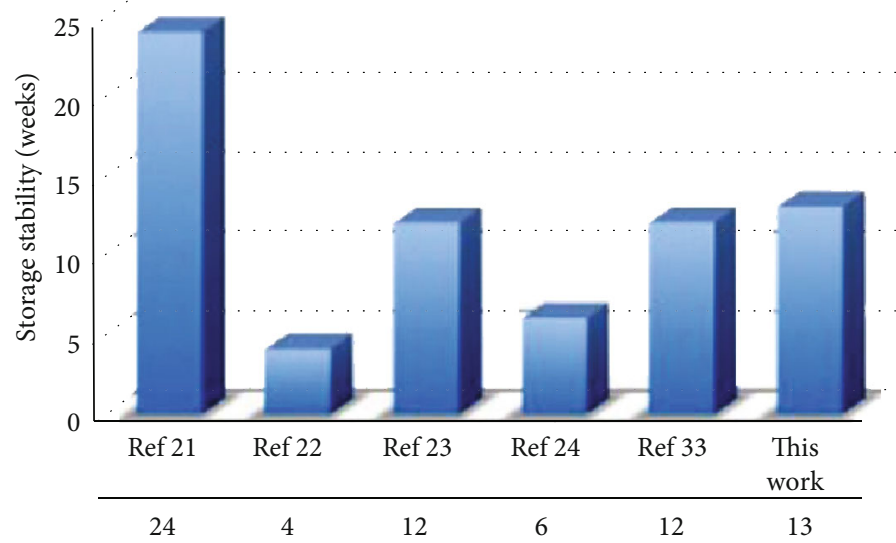

(c)

Figure 6: Continued. 


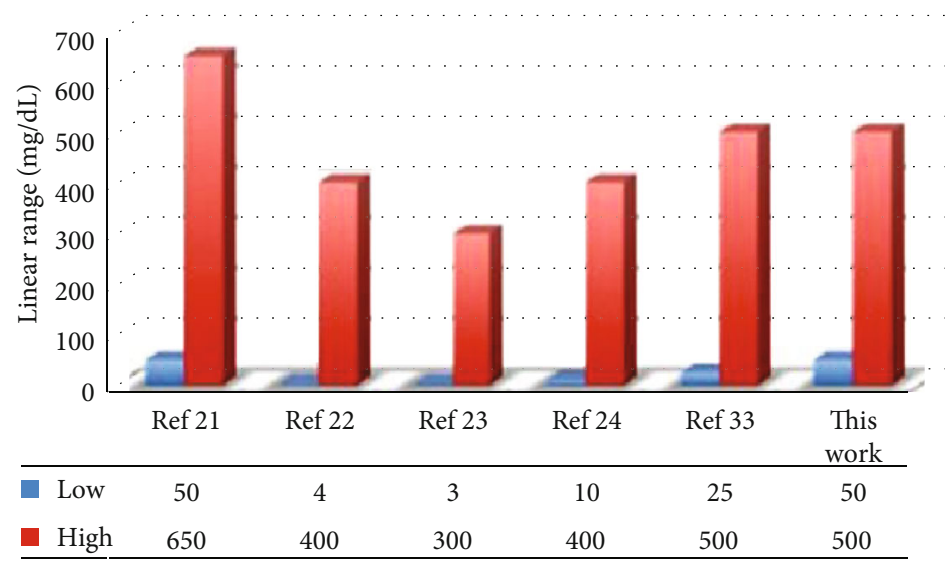

(d)

FIGURE 6: Comparative performance of different cholesterol biosensors: (a, b) sensitivity, (c) storage stability, and (d) linear range of cholesterol biosensor.

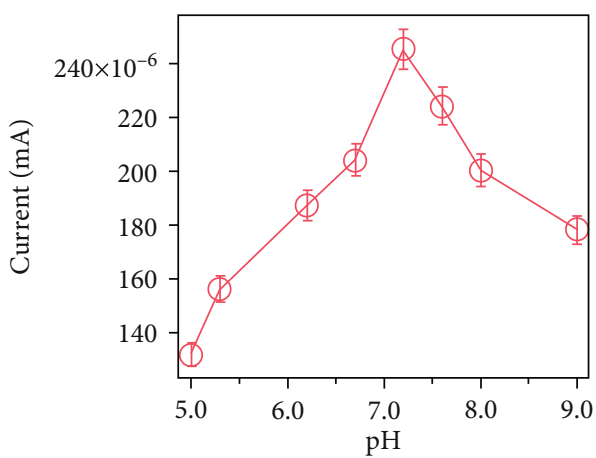

(a)

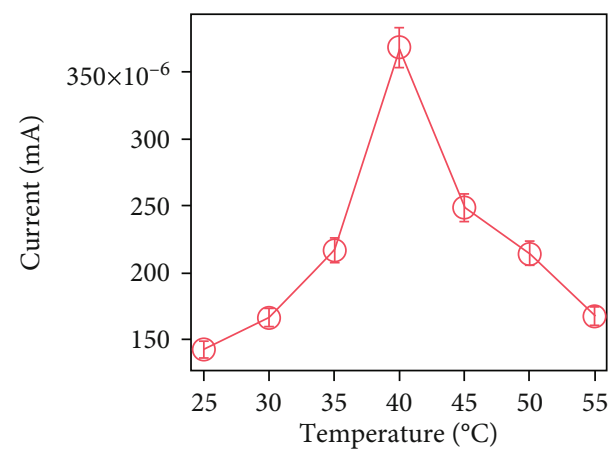

(b)

Figure 7: Effect of (a) $\mathrm{pH}$ and (b) temperature on the response of $\mathrm{ChOx} / \mathrm{CeO}_{2} \mathrm{NPs} / \mathrm{PPy}$ electrode with $200 \mathrm{mg} / \mathrm{dL}$ cholesterol.

in the figure is similar to that of the pristine $\mathrm{CeO}_{2} \mathrm{NPs}$. The obtained results indicate that the crystal structure of the $\mathrm{CeO}_{2}$ NPs was unmodified by pure PPy. However, when PPy was used to modify the $\mathrm{CeO}_{2} \mathrm{NPs}$, the diffraction peak intensity of the sample was reduced with respect to that of the pristine $\mathrm{CeO}_{2}$ NPs.

Figure 2(b) shows the energy dispersive X-ray spectroscopy (EDS) of the $\mathrm{CeO}_{2} \mathrm{NPs} / \mathrm{PPy}$ nanocomposite. As shown in Figure 2(b), the presence of $\mathrm{Ce}$ and $\mathrm{O}$ was associated with the $\mathrm{CeO}_{2}$ NPs. The carbon elements were related to the PPy. No contaminating elements could be found in the $\mathrm{CeO}_{2}$ NPs/PPy during sample preparation, as no other peaks were detected except for the $\mathrm{Si}$ and $\mathrm{Pt}$ peaks originating from the substrate.

3.2. Electrical Conductivity Characterization of the $\mathrm{CeO}_{2}$ NPs/PPy Nanocomposite. The electrical conductivity of the $\mathrm{CeO}_{2}$ NPs/PPy nanocomposite as a function of the $\mathrm{CeO}_{2}$ concentration at room temperature is shown in Figure 3. The pure PPy electrical conductivity was obtained at approximately $11.3 \mathrm{~S} / \mathrm{cm}$. The conductivity increased to $23.1 \mathrm{~S} / \mathrm{cm}$ when the $\mathrm{CeO}_{2} \mathrm{NP}$ amount of up to $25 \mathrm{wt}$.\% was added; then, it decreased at the higher $\mathrm{CeO}_{2} \mathrm{NP}$ concentration. This result is the same as the result obtained by Seema and Prasad [30], who determined that electrical conductivity was due to the excessive formation of charge carriers. Here, the decrease in conductivity may be due to the relatively large dimension of the $\mathrm{CeO}_{2}$ NPs, which hinders the hopping of the charge carrier.

3.3. Electrochemical Characterization of Cholesterol Biosensor. CV is a powerful tool for evaluating the interfacial properties of biosensors. Figure 4 shows the $\mathrm{CV}$ results of the cholesterol biosensor in the PBS solution ( $\mathrm{pH}$ 7.4) containing the $\left[\mathrm{Fe}(\mathrm{CN})_{6}\right]^{3-/ 4-}$ mediator within the range of $0.0-0.8 \mathrm{~V}$ and a scan rate of $100 \mathrm{~V} / \mathrm{s}$. The oxidation current peaks in the figure are $78.6 \times 10^{-6}, 107 \times 10^{-6}$, and $131 \times 10^{-6} \mathrm{~mA}$ for the bare electrode, $\mathrm{CeO}_{2} \mathrm{NPs} /$ electrode, and PPy/electrode, respectively. The results pertaining to the increasing oxidation current can be explained by the increasing electroactive electrode surface, which has led to the increasing electrochemical response. The oxidation current peak continuously further increased to $185 \times 10^{-6} \mathrm{~mA}$ when the $\mathrm{CeO}_{2}$ NPs/PPy nanocomposite-modified electrode facilitated the electron transfer of the redox probe $\left[\mathrm{Fe}(\mathrm{CN})_{6}\right]^{3-/ 4-}$ between the electrolyte solution and the electrode. A decrease 


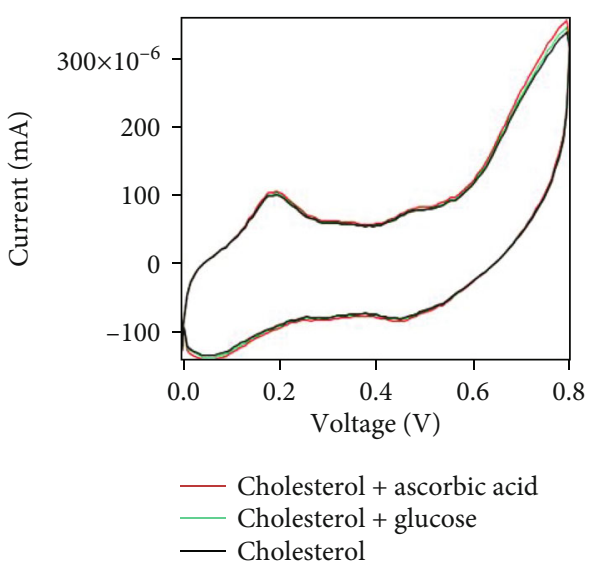

(a)

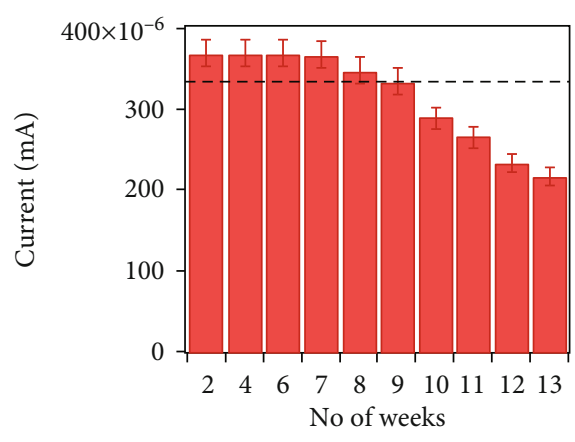

(b)

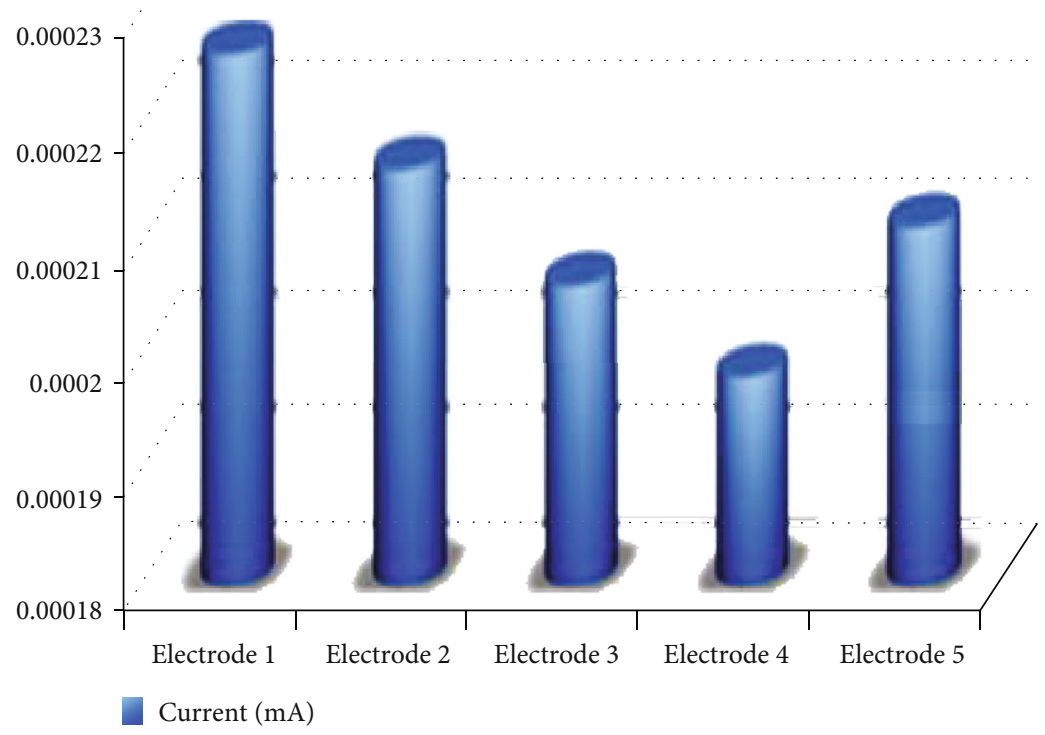

(c)

Figure 8: Results of (a) selectivity and (b) storage stability and (c) reproducibility of $\mathrm{ChOx} / \mathrm{CeO}_{2} \mathrm{NPs} / \mathrm{PPy} /$ electrode measured at $100 \mathrm{mV} / \mathrm{s}$ scan rates in the presence of $200 \mathrm{mg} / \mathrm{dL}$ cholesterol concentration.

in oxidation current peak was observed at $158 \times 10^{-6} \mathrm{~mA}$ after $\mathrm{ChOx}$ was attached onto the $\mathrm{CeO}_{2} \mathrm{NPs} / \mathrm{PPy} /$ electrode surface, which formed a thick film. The electron transfer was inhibited due to the insulating nature of the bulky protein molecules. The oxidation current was significantly enhanced at $198 \times 10^{-6} \mathrm{~mA}$ for the $\mathrm{ChOx} / \mathrm{CeO}_{2} \mathrm{NPs} / \mathrm{PPy} / \mathrm{e}-$ lectrode in the presence of $200 \mathrm{mg} / \mathrm{dL}$ cholesterol in the PBS buffer. This finding may be explained as follows:

$$
\text { Cholesterol }+\mathrm{O}_{2}(\mathrm{ChOx})>\text { Cholestenone }+\mathrm{H}_{2} \mathrm{O}_{2} \text {, }
$$

$$
\mathrm{H}_{2} \mathrm{O}_{2}>\frac{1}{2 \mathrm{O}_{2}}+\mathrm{H}_{2} \mathrm{O}+2 \mathrm{e}^{-} .
$$

In reaction (1), cholesterol was first oxidized by oxygen to form cholestenone and $\mathrm{H}_{2} \mathrm{O}_{2}$ in the presence of ChOx. Then, $\mathrm{H}_{2} \mathrm{O}_{2}$ was reduced at the electrode surface to produce elec- trons [31]. The $\mathrm{CeO}_{2} \mathrm{NPs} / \mathrm{PPy}$ nanocomposite transferred the electrons to the electrode via probe indicator conversion, resulting in an increased oxidation current peak. This oxidation current peak response is directly proportional to the added cholesterol concentration, as illustrated in Figure 5.

As shown in Figure 5(a), the oxidation current peak increases along with the varying amounts of cholesterol from 50 to $500 \mathrm{mg} / \mathrm{dL}$ in the PBS buffer (pH 7.4) at the $100 \mathrm{mV} / \mathrm{s}$ scan rate. The cholesterol was oxidized in the presence of $\mathrm{ChOx}$, which generated a number of electrons, as described in reaction (2). The calibration plots of the $\mathrm{ChOx} / \mathrm{CeO}_{2}$ $\mathrm{NPs} / \mathrm{PPy} /$ electrode are replotted from the $\mathrm{CV}$ response, as shown in Figure 5(b). A linear relationship, with the cholesterol concentration ranging from 50 to $500 \mathrm{mg} / \mathrm{dL}$, was observed following the linear regression equation of $Y(\mathrm{~mA}$ )$=9.27 \times 10^{-5}+5.7 \times 10^{-6} \times[$ cholesterol $](\mathrm{mg} / \mathrm{dL})$. The sensitivity of the cholesterol biosensor calculated from the slope 
of the calibration curve was $5.7 \times 10^{-6} \mathrm{~mA} / \mathrm{mg} \cdot \mathrm{dL}^{-1}$. A comparison of the developed biosensor with other cholesterol biosensors is presented in Figure 6. As shown in Figures 6(a) and (b), the developed cholesterol biosensor sensitivity is higher than those in the findings of Tiwari and Gong [20] and Wisitsoraat et al. [21], whereas it is lower than those in the findings of Khan et al. [22], Ansari et al. [23], and Dhand et al. [32]. The shelf life of the developed sensor is 13 weeks, which is better than that found by Wisitsoraat et al. [21], Khan et al. [22], Ansari et al. [23], and Dhand et al. [32] (Figure 6(c)). The linear range of the developed cholesterol biosensor is also good with respect to those of the other group (Figure 6(d)).

3.4. Optimal of the Experimental Conditions. The cholesterol biosensor was optimized for the $\mathrm{pH}$ value (Figure $7(\mathrm{a})$ ). The magnitude of the oxidation current peak increased with the increase in $\mathrm{pH}$ from 5.0 to 7.4. The change in oxidation current peak with varying $\mathrm{pH}$ values can be attributed to the enzyme with maximum activity and the ChOx that was not denatured and thus had retained its natural structure. The oxidation current peak was reduced with the further increase in $\mathrm{pH}$ from 7.4 to 9.0. This condition may be due to the activity loss of the ChOx enzyme at the high $\mathrm{pH}$ value. Thus, the $\mathrm{pH}$ of 7.4 was used as the optimal value in all of the succeeding experiments.

The effect of working temperature on cholesterol biosensor response was studied in the range of $25^{\circ} \mathrm{C}$ to $55^{\circ} \mathrm{C}$. As presented in Figure $7(\mathrm{~b})$, the output signal of the biosensor increases with the increase in temperature to up to $40^{\circ} \mathrm{C}$, and the value decreases when the temperature continuously increases above $40^{\circ} \mathrm{C}$. This trend may be due to the enzymes that could have been denatured at the high temperature, thus losing their catalytic activity. The temperature of $40^{\circ} \mathrm{C}$ was considered the optimal temperature for cholesterol biosensor response. However, subsequent experiments were performed at room temperature for practical applications.

3.5. Selectivity, Storage Stability, and Reproducibility of the Cholesterol Biosensor. The selectivity measurements of the $\mathrm{ChOx} / \mathrm{CeO}_{2} \mathrm{NPs} / \mathrm{PPy} /$ electrode were evaluated in PBS containing $200 \mathrm{mg} / \mathrm{dL}$ cholesterol with and without glucose and ascorbic acid. The fabricated biosensor was negligibly influenced by interferences (Figure 8(a)). The response values of $2.67 \%$ and $2.36 \%$ accounted for $90 \mathrm{mg} / \mathrm{dL}$ glucose and $20 \mathrm{mg} / \mathrm{dL}$ ascorbic acid, respectively. The obtained results indicate that the $\mathrm{ChOx} / \mathrm{CeO}_{2} \mathrm{NPs} / \mathrm{PPy} /$ electrode is highly selective for practical applications.

The storage stability of the $\mathrm{ChOx} / \mathrm{CeO}_{2} \mathrm{NPs} / \mathrm{PPy} / \mathrm{elec}-$ trode was further studied by storing it in $\mathrm{PBS}$ at $4^{\circ} \mathrm{C}$; then, its response was tested (Figure 8(b)). The electrode activity retained $90 \%$ of its initial response after 9 weeks. After 13 weeks, the electrode response was $63 \%$, which is higher than the value reported in the literature [21-23, 32].

Five different $\mathrm{ChOx} / \mathrm{CeO}_{2} \mathrm{NPs} / \mathrm{PPy} /$ electrodes were prepared, and their electrochemical responses were studied in PBS containing $200 \mathrm{mg} / \mathrm{dL}$ cholesterol. The CV technique was used to evaluate the reproducibility of the cho- lesterol biosensor. As shown in Figure 8(c), all of the fabricated biosensors have the same response characterizations. The relative standard deviation of the parallel measurements for the five modified electrodes was 3.3\%. This finding confirms that the cholesterol biosensor has good reproducibility.

\section{Conclusion}

In this study, we developed a cholesterol biosensor by using the $\mathrm{CeO}_{2}$ NPS/PPy nanocomposite as the mediator to immobilize $\mathrm{ChOx}$ onto the electrode surface. The results confirm that the fabricated $\mathrm{ChOx} / \mathrm{CeO}_{2} \mathrm{NPs} / \mathrm{PPy} /$ electrode has a wide linear response range $(50-500 \mathrm{mg} / \mathrm{dL})$ and high sensitivity $\left(5.7 \times 10^{-6} \mathrm{~mA} / \mathrm{mg} \cdot \mathrm{dL}^{-1}\right)$. In addition, the cholesterol biosensor exhibited good selectivity and reproducibility and acceptable storage stability. These results indicate that the developed cholesterol biosensor can be used as a useful tool for cholesterol detection in clinical diagnostics.

\section{Data Availability}

The data presented in this study are available on request from the corresponding author.

\section{Conflicts of Interest}

The authors declare that they have no conflicts of interest.

\section{Acknowledgments}

This work is funded by the Vietnam National Foundation for Science and Technology Development (Grant No. 103.022019.337).

\section{References}

[1] H. B. Ma and K. J. Shieh, "Cholesterol and human health," The Journal of American Science, vol. 2, pp. 46-50, 2006.

[2] M. Nauck, W. Marz, and H. Wieland, "Is lipoprotein(a) cholesterol a significant indicator of cardiovascular risk?," Clinical Chemistry, vol. 46, no. 3, pp. 436-437, 2000.

[3] K. Hojo, H. Hakamata, A. Ito et al., "Determination of total cholesterol in serum by high-performance liquid chromatography with electrochemical detection," Journal of Chromatography A, vol. 1166, no. 1-2, pp. 135-141, 2007.

[4] K. Osada, A. Ravandi, and A. Kuksis, "Rapid analysis of oxidized cholesterol derivatives by high-performance liquid chromatography combined with diode-array ultraviolet and evaporative laser light-scattering detection," Journal of the American Oil Chemists' Society, vol. 76, no. 7, pp. 863-871, 1999.

[5] M. A. Paulazo and A. O. Sodero, "Analysis of cholesterol in mouse brain by HPLC with UV detection," PLoS one, vol. 15, no. 1, article e0228170, 2020.

[6] H. I. Oh, T. S. Shin, and E. J. Chang, "Determination of cholesterol in milk and dairy products by high-performance liquid chromatography," Asian-Australasian Journal of Animal Sciences, vol. 14, no. 10, pp. 1465-1469, 2001.

[7] K. Z. Liu, M. Shi, A. Man, T. C. Dembinski, and R. A. Shaw, "Quantitative determination of serum LDL cholesterol by 
near-infrared spectroscopy," Vibrational Spectroscopy, vol. 38, no. 1-2, pp. 203-208, 2005.

[8] J. Wang, Y. J. Geng, B. Guo et al., "Near-infrared spectroscopic characterization of human advanced atherosclerotic plaques," Journal of the American College of Cardiology, vol. 39, no. 8, pp. 1305-1313, 2002.

[9] J. Chitra, M. Ghosh, and H. N. Mishra, "Rapid quantification of cholesterol in dairy powders using Fourier transform near infrared spectroscopy and chemometrics," Food Control, vol. 78, pp. 342-349, 2017.

[10] T. Lin, L. Zhong, H. Chen et al., "A sensitive colorimetric assay for cholesterol based on the peroxidase-like activity of $\mathrm{MoS}_{2}$ nanosheets," Microchimica Acta, vol. 184, no. 4, pp. 12331237, 2017.

[11] X. Li, Z. Pu, and H. Zhou, "Synergistically enhanced peroxidase-like activity of $\mathrm{Pd}$ nanoparticles dispersed on $\mathrm{CeO}_{2}$ nanotubes and their application in colorimetric sensing of sulfhydryl compounds," Journal of Materials Science, vol. 53, no. 19, pp. 13912-13923, 2018.

[12] Y. Lia, Z. Kang, L. Kong et al., "MXene- $\mathrm{Ti}_{3} \mathrm{C}_{2} / \mathrm{CuS}$ nanocomposites: enhanced peroxidase-like activity and sensitive colorimetric cholesterol detection," Materials Science \& Engineering C, vol. 104, article 110000, 2019.

[13] A. K. Giri, C. Charan, A. Saha, V. K. Shahi, and A. B. Panda, "An amperometric cholesterol biosensor with excellent sensitivity and limit of detection based on an enzymeimmobilized microtubular ZnO@ZnS heterostructure," Journal of Materials Chemistry A, vol. 2, no. 40, pp. 1699717004, 2014.

[14] U. Saxena and A. B. Das, "Nanomaterials towards fabrication of cholesterol biosensors: key roles and design approaches," Biosensor and Bioelectronic, vol. 75, pp. 196-205, 2016.

[15] M. Dervisevic, E. Çevik, M. Şenel, C. Nergiz, and M. F. Abasiyanik, "Amperometric cholesterol biosensor based on reconstituted cholesterol oxidase on boronic acid functional conducting polymers," Journal of Electroanalytical Chemistry, vol. 776, pp. 18-24, 2016.

[16] X. Lin, Y. Ni, and S. Kokot, "Electrochemical cholesterol sensor based on cholesterol oxidase and $\mathrm{MoS}_{2}$-AuNPs modified glassy carbon electrode," Sensors and Actuators B: Chemical, vol. 233, pp. 100-106, 2016.

[17] A. Ahmadalinezhad and A. Chen, "High-performance electrochemical biosensor for the detection of total cholesterol," Biosensors and Bioelectronics, vol. 26, no. 11, pp. 4508-4513, 2011.

[18] C. Jianrong, M. Yuqing, H. Nongyue, W. Xiaohua, and L. Sijiao, "Nanotechnology and biosensors," Biotechnology Advances, vol. 22, no. 7, pp. 505-518, 2004.

[19] M. Mehrvar and M. Abri, "Recent developments, characteristics, and potential applications of electrochemical biosensors," Analytical Science, vol. 20, no. 8, pp. 1113-1126, 2004.

[20] A. Tiwari and S. Gong, "Electrochemical study of chitosan$\mathrm{SiO}_{2}$-MWNT composite electrodes for the fabrication of cholesterol biosensors," Electroanalysis, vol. 20, no. 19, pp. 21192126, 2008.

[21] A. Wisitsoraat, P. Sritongkham, C. Karuwan, D. Phokharatkul, T. Maturos, and A. Tuantranont, "Fast cholesterol detection using flow injection microfluidic device with functionalized carbon nanotubes based electrochemical sensor," Biosensors and Bioelectronics, vol. 26, no. 4, pp. 1514-1520, 2010.

[22] R. Khan, A. Kaushik, P. R. Solanki, A. A. Ansari, M. K. Pandey, and B. D. Malhotra, "Zinc oxide nanoparticles-chitosan com- posite film for cholesterol biosensor," Analytica Chimica Acta, vol. 616, no. 2, pp. 207-213, 2008.

[23] A. A. Ansari, A. Kaushik, P. R. Solanki, and B. D. Malhotra, "Electrochemical cholesterol sensor based on tin oxidechitosan nanobiocomposite film," Electroanalysis, vol. 8, pp. 965-972, 2009.

[24] I. S. Chronakis, S. Grapenson, and A. Jakob, "Conductive polypyrrole nanofibers via electrospinning: electrical and morphological properties," Polymer, vol. 47, no. 5, pp. 1597-1603, 2006.

[25] K. Singh, P. R. Solanki, T. Basu, and B. D. Malhotra, "Polypyrrole/multiwalled carbon nanotubes-based biosensor for cholesterol estimation," Polymers for Advanced Technologies, vol. 23, no. 7, pp. 1084-1091, 2012.

[26] A. Pawaiya, N. Jadon, and R. Jain, "Polypyrrole-cerium oxide nano composite glassy carbon platform for the quantification of Torsemide," Insights Analytical Electrochemistry, vol. 4, pp. 1-10, 2018.

[27] B. O. Özer and S. Çete, "Development of a novel biosensor based on a polypyrrole-dodecylbenzene sulphonate (PPyDBS) film for the determination of amperometric cholesterol," Artificial Cells, Nanomedicine, and Biotechnology, vol. 45, no. 4, pp. 824-832, 2017.

[28] Y. Wang, X. Xiao, F. Zhang et al., "Synthesis of CeO2/PPy composites for use in the electrocatalytic detection of nitrite," Inorganic and Nano-Metal Chemistry, vol. 50, no. 12, pp. 1308-1314, 2020.

[29] N. T. Nguyet, L. T. H. Yen, V. Y. Doan et al., "A label-free and highly sensitive DNA biosensor based on the core-shell structured $\mathrm{CeO}_{2}$-NR@Ppy nanocomposite for Salmonella detection," Materials Science \& Engineering C, vol. 96, pp. 790797, 2019.

[30] S. Seema and M. V. N. A. Prasad, "Studies on DC conductivity and LPG sensing behaviour of nanostructured polypyrrole $\mathrm{CeO}_{2}$ composites," in , Article ID 030019AIP Conference Proceedings, vol. 1989, Solapur, India, 2018.

[31] T. T. N. Anh, L. T. Tam, V. V. Thu, A. T. Le, V. P. Hung, and P. D. Tam, "Nano-rods structured cerium oxide platform for cholesterol biosensor," Journal of Inorganic and Organometallic Polymers and Materials, vol. 30, no. 10, pp. 3886-3893, 2020.

[32] C. Dhand, M. D. G. Sumana, A. K. Srivastava et al., "Preparation, characterization and application of polyaniline nanospheres to biosensing," Nanoscale, vol. 2, no. 5, pp. 747-754, 2010. 